\title{
Silurian thelodonts from the Niur Formation, central Iran
}

Vachik Hairapetian, Henning Blom, and C. Giles Miller

Acta Palaeontologica Polonica 53 (1), 2008: 85-95 doi:http://dx.doi.org/10.4202/app.2008.0105

Thelodont scales are described from the Silurian Niur Formation in the Derenjal Mountains, east central Iran. The material studied herein comes from four stratigraphic levels, composed of rocks formed in a shallow water, carbonate ramp environment. The fauna includes a new phlebolepidiform, Niurolepis susanae gen. et sp. nov. of late Wenlock/?early Ludlow age and a late Ludlow loganelliiform, Loganellia sp. cf. L. grossi, which constitute the first record of these thelodont groups from Gondwana. The phlebolepidiform Niurolepis susanae gen. et sp. nov. is diagnosed by having trident trunk scales with a raised medial crown area separated by two narrow spiny wings from the lateral crown areas; a katoporodid-type histological structure distinguished by a network of branched wide dentine canals. Other scales with a notch on a smooth rhomboidal crown and postero-laterally down-stepped lateral rims have many characters in common with Loganellia grossi. Associated with the thelodonts are indeterminable acanthodian scales and a possible dentigerous jaw bone fragment. This finding also provides evidence of a hitherto unknown southward dispersal of Loganellia to the shelves of peri-Gondwana.

Key words: Thelodonti, Phlebolepidiformes, Loganelliiformes, palaeobiogeography, Silurian, Niur Formation, Iran.

Vachik Hairapetian vachik@khuisf.ac.ir, Department of Geology, Islamic Azad University, Khorasgan branch, PO Box 81595-158, Esfahan, Iran; Henning Blom henning.blom@ebc.uu.se, Subdepartment of Evolutionary Organismal Biology, Department of Physiology and Developmental Biology, Uppsala University, Norbyvägen 18A, SE-752 36 Uppsala, Sweden; C. Giles Miller g.miller@nhm.ac.uk, Department of Palaeontology, Natural History Museum, Cromwell Road, London SW7 5BD, UK.

This is an open-access article distributed under the terms of the Creative Commons Attribution License (for details please see creativecommons.org), which permits unrestricted use, distribution, and reproduction in any medium, provided the original author and source are credited. 
FoF Full text $(810.8 \mathrm{kB})$ 